
КРИМІНАЛЬНО-ВИКОНАВЧЕ ПРАВО

UDC 343.1

DOI https://doi.org/10.32782/2524-0374/2019-5/52

\title{
CRIMINAL AND LEGAL CHARACTERISTICS OF BUSINESS OFFENCES
}

\author{
КРИМІНАЛЬНО-ПРАВОВА ХАРАКТЕРИСТИКА ЗЛОЧИНІВ \\ У СФЕРІ ПІДПРИЕМНИЦЬКОЇ ДІЯЛЬНОСТІ
}

\author{
Didkivska H.V., Candidate of Law, Associate Professor, \\ Associate Professor of the Department of Criminal Law and Criminology \\ State Fiscal Service of Ukraine \\ Vitiuk I.A., Graduate Student \\ of the Department of Criminal Law and Criminology \\ State Fiscal Service of Ukraine
}

The article explores economic crimes that can be committed at all stages of the activity of the economic structure: shareholders can be deceived when investing in the statutory fund of the economic entity, and workers or employees - when calculating wages, bonuses and other allowances to material maintenance. Attention is also drawn to the production process, which can be carried out in such a way as to cause losses not only to competitors or consumers of products, works and services, but also to the environment. It is emphasized that the economic sphere should include the correctness of profit distribution, as it can be carried out in ways that are contrary to the current tax legislation.

The definition of crimes against the economy as illegal self-interest activities in the sphere of entrepreneurship aimed at obtaining material benefit personally and/or by third parties outside the state control of economic entities and individuals is presented. The criminal legal characteristics of crimes in the sphere of business and economic activity were considered and analyzed.

Since a very large number of crimes are committed in the sphere of economic activity, we have proposed certain areas of improvement of this sphere of activity, such as: 1 ) it is necessary to develop measures to register enterprises on the stock exchange, which makes it possible to protect shareholders by constantly receiving information about the issue of new shares by enterprises; 2) pay special attention to the fraud of enterprises with the provision of state grants and loans, as the state can be deceived by the economic entity by providing it with fictitious data: 3 ) it is advisable to introduce rules to protect the rights of buyers of shares from speculation by them; 4) it is necessary to pay attention to front contracts or system of foreign exchange revenue recognition; 5) the practice of offering significant money or other material goods to employees of firms or enterprises in exchange for industrial or commercial secrets is quite common. As such proposals are treated as bribery, the offender must be prosecuted for improper benefit, provided the proposals or demands of the business partner are satisfied.

Key words: crime, economy, crime, criminology, investment, prevention.

У статті досліджується економічні злочини, які можуть бути вчинені на всіх стадіях діяльності господарюючої структури: акціонери можуть бути ошуканими при вкладенні коштів до статутного фонду господарюючого суб'єкта, а робітники чи службовці - при нарахуванні їм заробітної плати, премій та інших надбавок до матеріального утримання. Звертається увага також на виробничий процес, який може здійснюватися таким чином, що наносяться збитки не лише конкурентам чи споживачам продукції, робіт та послуг, а й оточуючому середовищу.

Акцентується увага, що до сфери економіки необхідно віднести правильність розподілу прибутку, оскільки він може здійснюватись способами, що суперечать діючому податковому законодавству. Представлено визначення злочинів проти економіки як протиправної корисливої діяльності у сфері підприємництва направленої на отримання матеріальної вигоди особисто та/або третіми особами поза державним контролем суб'єктами господарювання і фізичними особами.

Розглянуто та проаналізовано кримінально-правову характеристику злочинів у сфері підприємницької діяльності та господарської діяльності. Так, як у сфері господарської діяльності скоюється дуже велика кількість злочинів, відтак авторами запропоновано певні напрями вдосконалення цієї сфери діяльності: 1) необхідно розробити заходи по реєстрації підприємств на біржі, що дає можливість захистити акціонерів завдяки постійному надходженню інформації про випуск підприємствами нових акцій; 2) особливу увагу звернути на махінації підприємств із наданням державних дотацій і позик, оскільки держава може бути обманута суб'єктом господарювання шляхом надання їй фіктивних даних; 3) доцільно запровадити правила захисту прав покупців акцій від спекулювання ними; 4) необхідно звертати увагу на підставні договори чи систему реалізації валютної виручки; 5) досить поширеною є практика пропозицій службовцям фірм чи підприємств значних грошових коштів чи інших матеріальних благ в обмін на промислові чи комерційні таємниці. Оскільки такі пропозиції розглядаються як підкуп, злочинець повинен притягуватись до кримінальної відповідальності за неправомірну вигоду при умові задоволення пропозицій чи вимог бізнесового партнера.

Ключові слова: злочинність, економіка, злочин, кримінологія, інвестиції, запобігання.

Statement of a problem. On the basis of studying of criminal activity of heads of enterprise subjects the tendency to reflection in reporting financial documents significant damage by write-off of fixed assets or current assets at much cut prices is revealed. Therefore, in order to eliminate such a mechanism of commission of crimes, it is necessary to develop measures for registration of enterprises on the stock exchange, which makes it possible to protect shareholders by constantly receiving information about the issue of new shares by enterprises. The accounts of such a case shall be constantly checked by the members of the audit commissions [3, p. 36].

Special attention should be paid to the fraud of enterprises with the provision of State grants and loans, as the State may be deceived by the economic entity by providing it with fictitious data.

Analysis of the last researches and publications. Questions of criminal liability for crimes in the sphere of economic activity it was put and in general it is solved in works of such scientists-criminalists: Item Andrushko, S. Antonov, M. Bazhanov, A. Benitsky, P. Berzin, V. Beletskii, V. Borisova, L. Brich, A. Vasiltseva, A. Volobueva, P. Vorobya, A. Gotin, A. Gutnik, N. Gutorov, A. Dudorov, M. Melnica, V. Moisik, M. Korzhanskiy, A. Krishevich, in Kuznetsova, V. Navrocki, Yu. Opalinsky, V. Ostanina, M. Panov, V. Popovich, A. Radutnoy, A. Savchenko, V. Stashisa, E. Shektsov, Y. Sukhova, S. Trofimov, M. Ha ronyuk, A. Charichanki, etc. 
Purpose of scientific research. - is to establish species objects included in section VII "Ranks in the sphere of economic activity" Special part of the Criminal Code, and definition on their The basis of the system of crimes in the sphere of some activities.

As for the correctness of tax distribution, the entrepreneur always has the opportunity to hide losses or show in the balance sheet and other reporting documents fictitious profit, which will allow to interest shareholders in acquiring their shares. At the same time, there are cases where an enterprise incorrectly reflects losses in order to force shareholders to sell shares at lower prices from their face value by deception. At the same time, in the accounts of the enterprise its managers reflect equity, consisting of available funds less debts. If for each reporting period the capital of the economic entity increases, it has the corresponding profit. In this case, it is possible to show sufficiently large rather small profits. When calculating to reflect losses, business managers underestimate profits or deliberately show payables. To be sure, both ways create conditions for fraud with both income and debt.

Statement of the main material. As practice has shown, it is advisable to introduce rules to protect the rights of stock buyers from speculation by them. For this purpose, the Criminal Code of Ukraine should be supplemented by an article providing for the liability of the heads of joint-stock companies for the conscious reduction of the nominal value of shares as a result of the loss-making activity of the face-taking. Note this, the annual report is the basis for deciding on the amount of dividend payment and is approved by the majority of shareholders. Such a provision could therefore block minority attempts to obtain an appropriate share of the enterprise's profits, thereby damaging the majority of shareholders who were unable to do so. Of course, the draft Law of Ukraine "On Joint Stock Companies" includes a number of provisions aimed at protecting shareholders. At the same time, other laws on the activities of enterprises in Ukraine do not contain similar provisions and the above-mentioned actions of the so-called minority are not punished by law [3, p. 38].

As the practice of small business structures shows, a significant number of criminal actions in the economic sphere are committed by economic partners through so-called credit fraud. Illegal acts by founders or heads of an economic entity are provided in advance. Such an offence is committed by raising at the initial stage of activity the authority of its own economic structure (timely settlements with suppliers of raw materials, semi-finished products or products, which are immediately sold to other partners). After some period the enterprise is declared bankrupt, having saved nothing for settlement with creditors of its economic structure.

The development of law enforcement agencies in recent years has confirmed the intensification of so-called artificial bankruptcy, the share of which among the cases considered by economic courts is almost one third of all functioning business entities. Bankruptcy in such cases does not mean that the debts disappeared, as after the declaration of bankruptcy the share of unpaid debts remains with the enterprise. If this economic structure has the status of a joint-stock company, there is little hope of returning their share to creditors. Of course, such an enterprise ceases to exist as a legal entity after bankruptcy. At the same time, when an individual entrepreneur is destroyed, he is personally responsible for the debts of the enterprise and will be forced to return them in court, that is, the crime in this case is recognized and the person is financially responsible for the commission of unlawful acts [6, p. 96].

The study of economic crime revealed another fact: when regulating the process of renting production, trading space or land. This regulation is that the amount of rent is determined taking into account the rent established for buildings owned by economic entities. Lease contracts are concluded on the basis of their own agreement between the parties, and the difference between the established value and the market value is appropriately distributed among the managers of the enterprises that conclude the relevant agreements [6, p. 108].

Economic crime should also include the abduction of intellectual property. Thus, if the enterprise uses a patent, technology or product, according to the legislation, other business entities are not entitled to use this technology for the production of the relevant product. Therefore, it is an economic crime to infringe on patents and samples of industrial products, as such infractions can cause significant losses.

As the practice confirms, quite often enterprises, afraid of infringements on the patent, do not hurry to receive it. Industrial espionage is aimed at identifying industrial secrets and data on research works. But interest will not be so much in research works. Quite close to encroaching on patents and samples of industrial products is a form of economic crime such as copying CDs, video and audio cassettes. There is a widely known "black" market for such goods in Ukraine [4, p. 419].

When it comes to the form of economic crime in which illegal acts are systematically carried out through tax fraud, it is useful to distinguish it as such as is committed by large and small economic entities.

Large enterprises can have a significant number of owners in which there would be certain contradictions through different production interests, so they control each other's activities, and reporting is periodically reviewed by members of the audit commission. At the same time, the State Tax Inspectorate has sufficient control over the activities of such enterprises. At the same time, large enterprises are difficult to control through significant amounts of their production or commercial activities. It becomes much more difficult to carry out control when there are subsidiaries in the economic entity.

In addition, corporate enterprises can independently set prices for goods, works or services performed, which are provided by one enterprise in cooperation with another. Domestic pricing in practice depends on the payment of taxes. If, for example, the Industrial Union of Donbass decides to supply metal to its subsidiary with a location in Russia where slightly lower taxes are set, profits will remain with the foreign subsidiary and losses - In Ukraine. In addition, the price sold by the Industrial Union of Donbass is almost impossible to determine, as there is no market for the sale of molten metal by the parent company. Practice therefore requires international principles to determine the mechanism for pricing international controls. In view of domestic price regulation, concern profits can thus be directed to countries with lower taxes [7, p. 211].

Another way to achieve the same result is by so-called «account redirection». For example, Delta plans to import shirts from China. The operation is carried out directly between Lviv and Beijing, prices are set at 10 conventional units per shirt. The contract is signed by a subsidiary in Beijing, which is directly owned by the Lviv company Delta. The unconditional buyer is considered a subsidiary, after receiving the cargo resells it to the main firm in Lviv, but already at the price of 12 conventional units per shirt. With the same mark-up, Delta sells shirts in Ukraine. Thus, abstracting from expenses, the profit is 2 conditional units from the product in Beijing, where from time to time the heads of the company from Lviv travel to perform certain functions $[5, \mathrm{p} .88]$.

Of course, the tax and other state bodies of Ukraine are unable to establish the relations that exist in the subsidiary. This causes not only tax evasion to the state budget, but also creates opportunities for the heads of the main enterprise to assign a share of the non-registered profit in Ukraine [2, p. 17].

At the same time, tax fraud is of a different nature in small enterprises, especially those established by members of the same family. One way is to be able to use cash for personal needs.

For example, a merchant receives products for sale without any registration; Tourist trips are made as business trips, and repair of a private house or apartment - as office premises and so on. 
So-called "hired" work has become common in the state. The essence of it is that orders are executed without proper registration according to labor legislation, which is not reported to tax authorities, as a rule, neither the executor nor the client. Thus, the employee evades taxes to the state budget, and the client does not pay value added tax, so he does not pay labor on a market value scale, and therefore does not incur losses in the form of taxes paid or social payments. Such unlawful acts require suspension by giving testimony when employees receive orders to perform certain works.

Conclusions. In addition, not only tax offences are committed against society. Due to internal price determination, the diversion of accounts of large enterprises in Ukraine violate the current currency legislation. In such a case, according to the study, it is necessary to pay attention to front contracts or the system of recognition of foreign exchange revenues. Thus, the Central GOC, having 24 million UAH unpaid taxes to the state budget, received 223 thousand dollars during the quarter US revenue. In order to avoid payment of taxes to the budget by the management of the Central Mining and Processing Plant, the scheme was used, according to which foreign exchange revenues were realized, and the received 434 thousand graven were credited to the bank's account. Further, to apply the assignment of the right of claim and transfer of debt 194 thousand. UAH was used for repayment of the loan, and 239 thousand. UAH - paid under contracts of cancellation of promissory notes. In this case, the bank received its commission as well.

On the basis of the contracts with "Komtek", a number of contracts transferred foreign exchange revenues from the export of iron ore raw materials to the foreign exchange account of "Komtek" instead of transferring them to the foreign exchange account of the mill, as assumed by foreign economic agreements.

Thus, the total proceeds to the Mill's "Komtek" account for one quarter alone amounted to 1250000 . US dollars.

A similar tax evasion scheme was applied at the Alchev Metallurgical Plant, where the non-payment to the state budget amounted to 50 million. UAH. [1, p. 106].

The practice of offering significant money or other material goods to employees of firms or enterprises in exchange for industrial or commercial secrets is quite common. As such proposals are treated as bribery, the offender must be prosecuted for improper benefit, provided the proposals or demands of the business partner are satisfied.

Taking into account the above, it is possible to define crimes against the economy as illegal self-interest activity in the sphere of entrepreneurship aimed at obtaining material benefit personally and/or to third parties outside the state control of economic entities and individuals.

\section{REFERENCES}

1. Даньшин И.Н. Преступность в сфрере экономики: некоторые уголовно-правовые и криминологические вопросы // Актуальные проблемы формирования правового государства. Х., 2013. С. 237.

2. Дарнопих Г.Ю. Економічна безпека держави в умовах трансформаційної економіки : автореф. дис. ... канд. юрид. наук. Х., 2010. 17 c.

3. Петрушенко М. Тінь повинна засвітитися // Урядовий кур'єр. 2013. 13 лютого. 124 с.

4. Мандибура В.О. Шляхи подолання економічної злочинності і корупції в Україні // Економічні злочини: попередження і боротьба з ними. Міжнародний науковий збірник / за ред. А.І. Комарової та інші. Т. 25. К., 2011. 820 с.

5. Гуцалова К. Поняття та ознаки економічної злочинності: огляд літератури та проблемні питання // Підприємництво, господарство і право. 2016. № 10. С. $87-89$.

6. Мельник М.І. Корупція: сутність, поняття, заходи протидії : монографія. К. : Атіка, 2011. 304 с.

7. Костенко О.М., Шемшученко Ю.С. Щодо переваг системного підходу до боротьби з економічною злочинністю // Держава і право: зб. наук. праць. Юридичні і політичні науки. Вип. 18. К. : Ін-т держави і права НАН України, 2002. 510 с. 